\title{
Parapharygeal Space Tumours-Surgical Approach and Role of Tumour Markers
}

\author{
Pawan Singhal", Raghav Mehta, Sunita Agrawal, Digvijay Singh, Prakash Mishra \\ Department of E.N.T., S.M.S. Medical College and Hospital, Jaipur, India \\ Email: *drps.ent@gmail.com
}

Received July 18, 2013; revised August 15, 2013; accepted September 10, 2013

Copyright (c) 2014 Pawan Singhal et al. This is an open access article distributed under the Creative Commons Attribution License, which permits unrestricted use, distribution, and reproduction in any medium, provided the original work is properly cited. In accordance of the Creative Commons Attribution License all Copyrights (C) 2014 are reserved for SCIRP and the owner of the intellectual property Pawan Singhal et al. All Copyright @ 2014 are guarded by law and by SCIRP as a guardian.

\begin{abstract}
Both benign and malignant tumors may arise from any of the structures contained within the parapharyngeal space. Parapharyngeal space is difficult to reach and formidable area to approach by any surgeon. Due to its deep placement and approximation to vital structures, not only is tumour involving this space a difficult task to manage for the surgeon, but even its diagnosis may elude the doctor. Even the battery of clinical, biochemical or radiological tests diagnosis remains a difficult objective. We aim to provide an adjunct mode of aiding the diagnosis in the form of tumour markers. Though tumour markers alone are not sufficient, with the help of other tests, the diagnosis can be reached in a fairly accurate measure.
\end{abstract}

\section{KEYWORDS}

\section{Parapharyngeal Tumors; Tumor Markers; Shwannoma}

\section{Introduction}

The parapharyngeal space (PPS) is a potential space in the form of an inverted pyramid, with the base at the skull base and the tip at the hyoid bone. Medial wall is bounded by the superior constrictor muscle, lateral wall by ramus of mandible and posterior lined by prevertrbral muscles. The tensor veli palatini muscle attaching to styloid process divides the space into prestyloid and poststyloid spaces [1].

Both benign and malignant tumors may arise from any of the structures contained within the parapharyngeal space. Of parapharyngeal space tumors, $70 \%-80 \%$ are benign, and $20 \%-30 \%$ are malignant [2]. Most parapharyngeal space tumors are of salivary or neurogenic origin. Salivary gland neoplasms are located in prestyloid space and account for about $40 \%$ - 50\% of parapharyngeal space tumors (mostly pleomorphic adenomas of deep lobe). Neurogenic lesions are the most common tumors of the poststyloid parapharyngeal space and account for $25 \%-30 \%$ of parapharyngeal space lesions (mostly neurilemomas i.e. shwannomas). Metastatic tu-

${ }^{*}$ Corresponding author. mor or sarcoma, although rare, may also present as parapharyngeal space tumor.

Clinical detection is difficult. Tumor size should reach 2.5 to $3.0 \mathrm{~cm}$ to be detected clinically. Usually it presents with neck swelling (54\%), pain (11\%), cranial nerve palsy (10\%), oropharyngeal swelling (8\%), dysphagia (6\%) and others like unilateral eustachian tube dysfunction, dyspnea, obstructive sleep apnea, Horner syndrome, trismus and symptoms of catecholamine excess. Often an asymptomatic mass is seen which may be palpable at angle of mandible. Mild bulging of the soft palate or tonsillar region may be seen.

CT and MR scans are necessary for topographical diagnosis. In the case of pre-styloid tumours, if MR shows a fatty plane between the tumour and the parotid deep lobe, this would indicate that the tumour had separated from the lobe. To the contrary, absence of this plane would indicate that the tumour originated in the parotid deep lobe or, less frequently, was invading it. Low density lesions tend to be generally lipoma, liposarcoma or dermoids. Significantly enhancing lesions are Hemangiomas. The ones that are enhancing but extraparotid are usually shwannoma (esp. irregular enhancement known 
as salt-pepper appearance)

Once imaging tests have shown that it is not a vascular tumour, histological diagnosis is normally performed using Fine Needle Aspiration Cytology (over 93\% specific). Open biopsy is not advised, as it increases the risk of bleeding, breakage of the capsule, and accordingly, the seeding of the lesion. But if the lesion is vascular, then Angiogram has to be obtained.

Parapharyngeal space is difficult to reach and a formidable space to approach by any surgeons. Due to its deep placement and approximation to vital structure, not only is tumour involving this space a difficult task to manage for the surgeon but even the diagnosis may elude the doctor. Even the battery of clinical, biochemical or radiological tests diagnosis remains a difficult objective. We at S.M.S Medical College, Jaipur aim to provide an adjunct mode of aiding the diagnosis in the form of tumour markers. Though tumour markers alone are not sufficient, with the help of other tests, the diagnosis can be reached in a fairly accurate measure.

\section{Materials and Methods}

A Prospective study of 15 cases who presented to us from 2008 to 2011 was done. A rigid protocol of detailed history; physical examination was followed. A meticulous radiological examination was done including CT, MRI and if suspicion of vascular tumor then Angiogram was obtained. A fine needle aspiration was done to authenticate the diagnosis, direct biopsy was avoided. Even with these batteries of tests in few cases final diagnosis was not possible, these cases were subjected to tumor markers study. After the diagnosis surgical management was done preferring the Transcervical approach in maximum cases along with the use of Submandibular and Transparotid approach in some.

Follow-up was done after one week and then after 15 days for 3 months and then monthly for at least 1 year.

\section{Results and Analysis}

Over the period of 3 years 15 cases were operated and Parotid Adenoma was the most common diagnosis encountered in 4 cases, all were managed by Transcervicalsubmandibular approach. Two cases each of Neuroendocrine tumor and Schwannoma were operated via Transcervical approach. Only one case of Myoepithelioma of Parotid was operated via cervico parotid approach. As seen from the Table 1 below Transcervical approach was the most common approach used.

Table 1. Tumors and the surgical approaches.

\begin{tabular}{|c|c|c|c|c|c|c|}
\hline S.NO & AGE & SEX & HPE & SIDE & ROUTE & FOLLOW-UP \\
\hline 1 & 38 & M & SCHWANOMMA & LT. & TRANS-CERVICAL & GOOD \\
\hline 2 & 52 & $\mathrm{~F}$ & $\begin{array}{l}\text { NERVE SHEATH } \\
\text { TUMOR }\end{array}$ & RT. & $\begin{array}{l}\text { TRANSCERVICAL } \\
\text { SUBMANDIBULR }\end{array}$ & AVERAGE \\
\hline 3 & 40 & $\mathrm{~F}$ & LYMPHANGIOMA & LT. & $\begin{array}{l}\text { TRANSCERVICAL } \\
\text { SUBMANDIBULAR }\end{array}$ & GOOD \\
\hline 4 & 45 & $\mathrm{~F}$ & $\begin{array}{l}\text { PLEOMORPHIC } \\
\text { ADENOMA }\end{array}$ & LT. & $\begin{array}{l}\text { TRANSCERVICAL } \\
\text { SUBMANDIBULAR }\end{array}$ & GOOD \\
\hline 5 & 32 & $\mathrm{~F}$ & $\begin{array}{l}\text { PLEOMORPHIC } \\
\text { ADENOMA }\end{array}$ & RT. & TRANSCERVICAL & GOOD \\
\hline 6 & 55 & $\mathrm{~F}$ & LEIOMYO-SARCOMA & RT. & $\begin{array}{l}\text { TRANSCERVICAL } \\
\text { SUBMANDIBULAR }\end{array}$ & POOR (LATER LOST TO F/U) \\
\hline 7 & 65 & M & $\begin{array}{l}\text { CAROTID BODY } \\
\text { TUMOR }\end{array}$ & LT. & TRANSCERVICAL & $\begin{array}{l}\text { SHORT LASTING CEREBRAL } \\
\text { INFARCTION (APHASIA) }\end{array}$ \\
\hline 8 & 12 & M & LYMPНОMA & RT. & TRANSCERVICAL & AVERAGE \\
\hline 9 & 35 & $\mathrm{~F}$ & SCHWANOMMA & LT. & TRANSCERVICAL & GOOD \\
\hline 10 & 28 & $\mathrm{~F}$ & $\begin{array}{l}\text { PLEOMORPHIC } \\
\text { ADENOMA }\end{array}$ & RT. & $\begin{array}{l}\text { TRANSCERVICAL } \\
\text { SUBMANDIBULAR }\end{array}$ & GOOD \\
\hline 11 & 21 & M & $\begin{array}{l}\text { SYNOVIAL CELL } \\
\text { SARCOMA }\end{array}$ & RT. & TRANSCERVICAL & GOOD \\
\hline 12 & 47 & M & $\begin{array}{c}\text { NEUROENDOCRINE } \\
\text { TUMOR }\end{array}$ & RT. & TRANSCERVICAL & GOOD \\
\hline 13 & 38 & M & $\begin{array}{l}\text { MYOEPITHELIOMA } \\
\text { PAROTID }\end{array}$ & RT. & $\begin{array}{l}\text { CERVICO - } \\
\text { PAROTID }\end{array}$ & GOOD \\
\hline 14 & 62 & M & $\begin{array}{c}\text { PLEOMORPHIC } \\
\text { ADENOMA }\end{array}$ & RT & $\begin{array}{l}\text { TRANSCERVICAL } \\
\text { SUBMANDIBULAR }\end{array}$ & GOOD \\
\hline 15 & 35 & M & $\begin{array}{c}\text { NEUROENDOCRINE } \\
\text { TUMOR }\end{array}$ & LT & TRANSCERVICAL & GOOD \\
\hline
\end{tabular}

Abb: $-\mathrm{M}=$ Male, $\mathrm{F}=$ Female, $\mathrm{RT}=$ Right, $\mathrm{LT}=$ Left HPE = Histopathological Examination. 
Overall the follow-up was good, one case was lost to follow-up and one case of carotid body tumor developed short term cerebral infarction leading to aphasia which ultimately resolved in due course of time.

Out of the 15 cases we had, initial diagnosis was inconclusive in 5 cases, but after tumour marker studies the diagnosis was confirmed. As seen from the Table 2, neuroendcorine tumours which were diagnosed as Benign epithelial Neoplasm and Monomorphic salivary adenoma had confirmation of diagnosis after tumour marker study.

\section{Discussion}

Parapharyngeal tumours are rare entities which present very late in there evolution making them a difficult diagnosis in their early stages

Radiological diagnosis is by CT or MRI. If MR shows a fatty plane between the tumour and the parotid deep lobe, this would indicate that the tumour had separated from the lobe. To the contrary, absence of this plane would indicate that the tumour originated in the parotid deep lobe or, less frequently, was invading it [2-4].

If the radiological picture is non vascular then a FNAC is done to get the diagnosis. Open biopsy is not advised, as it increases the risk of bleeding, breakage of the capsule and, accordingly, the seeding of the lesion [5,6].

The surgical approach best applied to the parapharyngeal space tumours is an external one, which affords adequate visualization, control of bleeding, and identification of major vessels and nerves [7]. Internal approaches are to be discouraged, except perhaps in the rare circumstance of an extremely small lesion localized to the medial aspect of the space that can clearly be defined as such. Hughes et al. [8] and Malone et al. [9] in their study mostly used the transcervical approach, though Hughes et al used the transparotid approach also but trancervical was the most common one. McElroth [10] and Ehrilch [11] described the transoral approach but this was limited for small non vascular tumours as it gives limited access and difficult control of bleeding.

In our study we managed maximum cases with Transcervicval approach, transcervical with submandibular was used in 6 cases and one required cervico parotid approach. Transcervical approach gives a better access and good control of the field large tumours can be removed but even with this approach full vision of the lesion may not be possible so use of blunt dissection is undertaken. Some authors differentiate between the approach needed for excision of paragangliomas and other small poststyloid parapharyngeal space tumours and that used for excision of the prestyloid parapharyngeal space lesions. The former called "transcervical approach" is done without entrance of submandibular triangle. The latter called "transcervical submandibular" approach is done with dissecting the submandibular triangle by retraction of posterior belly of digastric muscle, permitting division and ligation of facial artery, then removal of submandibular gland, division of digastric tendon may be required if large tumours are encountered [12-14].

In short, the success of parapharyngeal tumor surgery depends on two conditions: correct identification and proper exposure of the lesion, allowing for complete removal; and minimum functional and aesthetic morbidity as a consequence of the surgery. Most patients may benefit from a simple transcervical or transparotid approach, but a group of patients with larger tumours require the use of techniques which, while simple, in combination may widen the surgical field without necessarily increasing morbidity. It is, accordingly, necessary to use all available surgical resources, adapting the chosen approach to the characteristics of the lesion.

The use of Tumour markers though still in stages of its infancy is the most lucrative field to be studied for future prospects. In our study we were able to diagnose 5 cases with surety whose initial diagnosis was inconclusive. Thus tumour markers are the potential for future diagnosis and subsequent targeted management of the these parapaharyngeal tumours.

Table 2. Marker study and pre- and post-operative diagnosis.

\begin{tabular}{llll}
\hline Initial Diagnosis & Tumour marker Used & Diagnosis after marker study & Final Diagnosis \\
\hline Inconclusive & SMA And Vimentin +ve & Leiomyosarcoma \\
$\begin{array}{lll}\text { Suggestive of spindle cell neop- } \\
\text { lasm? Neurilemmoma }\end{array}$ & $\begin{array}{l}\text { +ve for EMA \& Focal CK } \\
\text {-ve for Desmin, S-100 \& CD-99 }\end{array}$ & Synovial cell sarcoma \\
Benign epithelial Neoplasm & $\begin{array}{l}\text { +ve for CK, Chromogranin, } \\
\text { Synaptophysin \& bcl-2 }\end{array}$ & Neuroendocrine tumours \\
Monomorphic salivary adenoma & $\begin{array}{l}\text { +ve for CK, Chromogranin, } \\
\text { Synaptophysin \& bcl-2 }\end{array}$ & $\begin{array}{l}\text { Neuroendocrine tumours } \\
\text { Spindle cell Neoplasm }\end{array}$ & $\begin{array}{l}\text { Benign Myoepithelioma } \\
\text { +ve for SMA \& S-100 }\end{array}$ \\
\hline
\end{tabular}

Abb: - SMA = Smooth Muscle Actin, EMA = Epithelial Membrane Antigen, CK = Cytokeratin. 


\section{Conclusion}

Primary parapharyngeal tumors are rare and located in a complex anatomical region. The clinical presentation of these tumors can be subtle. Therefore radiographic study provides important information for diagnosis and surgical planning. Majority of the tumors are benign with salivary gland neoplasm being the most common tumor. Surgical resection is the mainstay of treatment. Transcervial with or without mandibulotomy is preferred by most surgeons. Tumour Marker Study aids in reaching the right diagnosis in conjugation with other tests, even in initially proven inconclusive cases.

\section{REFERENCES}

[1] H. Rouviére, A. Delmas, “Anatomía Topográfica de la Cabeza y el cuello. En: Anatomía Humana descriptiva, Funcionaly Topográfica,” Editorial Masson, Barcelona, 1987, pp. 550-556.

[2] A. Khafif, Y. Segev, D. M. Kaplan, Z. Gil and D. M. Fliss, "Surgical Management of Parapharyngeal Space tumors: A 10-Year Review,” Otolaryngology-Head and Neck Surgery, Vol. 132, No. 3, 2005, pp. 401-406. http://dx.doi.org/10.1016/j.otohns.2004.09.062

[3] J. Rodríguez-Ciurana, C. Rodado, M. Sáez, C. Bassas, "Giant Parotid Pleomorphic Adenoma Involving the Parapharyngeal Space: Report of a Case,” Journal of Oral and Maxillofacial Surgery, Vol. 58, No. 10, 2000, pp. 11841187. http://dx.doi.org/10.1053/joms.2000.9587

[4] D. E. Eisele, J. L. Netterville, H. T. Hoffman and B. J. Gantz, "Parapharyngeal Space Masses," Head \& Neck, Vol. 21, No. 2, 1999, pp. 154-159. http://dx.doi.org/10.1002/(SICI)1097-0347(199903)21:2< 154::AID-HED9>3.0.CO;2-W

[5] L. Acosta, P. Montalvão, M. Magalhães, J. Olias and N. Santiago, "Parapharyngeal Space Tumors. Our experience. I.P.O. Francisco Gentil, Lisbon,” Acta Otorrinolaringológica Española, Vol. 53, No. 7, 2002, pp. 485-490.

\section{http://dx.doi.org/10.1016/S0001-6519(02)78340-4}

[6] H. M. Morfit, "Retromandibular Parotid Tumors; Their Surgical Treatment and Mode of Origin," A.M.A. Archives of Surgery, Vol. 70, No. 6, 1955, pp. 906-913. http://dx.doi.org/10.1001/archsurg.1955.01270120114013

[7] A. Hamza, J. J. Fagan, J. L. Weissman and E. N. Myers, "Neurilemomas of the Parapharyngeal Space," Archives of Otolaryngology_Head \& Neck Surgery, Vol. 123, No. 6, 1997, pp. 622-626. http://dx.doi.org/10.1001/archotol.1997.01900060064011

[8] K. V. Hughes 3rd, K. D. Olsen and T. V. McCaffrey, "Parapharyngeal Space Neoplasms," Head Neck, Vol. 17, No. 2, 1995, pp. 124-130. http://dx.doi.org/10.1002/hed.2880170209

[9] J. P. Malone, A. Agrawal and D. E. Schuller, "Safety and Efficacy of Trans-Cervical Resection of Parapharyngeal Space Neoplasms," Annals of Otology, Rhinology, and Laryngology, Vol. 110, No. 12, 2001, pp. 1093-1098.

[10] D. C. McElroth, W. H. Remine and K. D. Devine, “Tumours of the Parapharyngeal Region," Surgery Gynecology and Obstetrics, Vol. 116, 1963, pp. 88-86.

[11] H. Ehrlich, "Mixed Tumors of the Pterygomaxillary Space; Operative Removal; Oral Approach,” Oral Surgery, Oral Medicine, Oral Pathology and Oral Radiology, Vol. 3, No. 11, 1950, pp. 1366-1371. http://dx.doi.org/10.1016/0030-4220(50)90297-0

[12] I. M. Ariel, A. P. Jerome and G. T. Pack, "Treatment of Tumors of the Parotid Salivary Gland,” Surgery, Vol. 35, No. 1, 1954, pp. 124-158.

[13] N. Lazaridis and K. Antoniades, "Double Mandibular Osteotomy with Coronoidectomy for Tumours in the Parapharyngeal Space," British Journal of Oral and Maxillofacial Surgery, Vol. 41, No. 3, 2003, pp. 142-146. http://dx.doi.org/10.1016/S0266-4356(03)00077-9

[14] U. Fisch, "Infratemporal Fossa Approach to Tumours of the Temporal Bone and Base of the Skull," The Journal of Laryngology \& Otology, Vol. 92, No. 11, 1978, pp. 949-967. http://dx.doi.org/10.1017/S0022215100086382 